\title{
Haloferax volcanii as immobilised whole cell biocatalyst: new applications for halophilic systems
}

\author{
R. U. Haque ${ }^{1,2} \cdot$ F. Paradisi ${ }^{2} \cdot$ T. Allers $^{1} \mathbb{D}$
}

Received: 8 November 2018 /Revised: 18 February 2019 / Accepted: 24 February 2019 /Published online: 15 March 2019

(C) The Author(s) 2019

\begin{abstract}
Enzyme-mediated synthesis of pharmaceutical compounds is a 'green' alternative to traditional synthetic chemistry, and microbial engineering opens up the possibility of using whole cells as mini-factories. Whole-cell biocatalysis reduces cost by eliminating expensive enzyme purification and cofactor addition steps, as well as resulting in increased enzyme stability. Haloferax volcanii is a model halophilic archaeon encoding highly salt and organic solvent tolerant enzymes such as alcohol dehydrogenase ( $H v \mathrm{ADH} 2)$, which catalyses the reduction of aldehydes and ketone in the presence of NADPH/NADH cofactor. A $H$. volcanii strain for constitutive $H v \mathrm{ADH} 2$ expression was generated using a strong synthetic promoter (p.syn). The strain was immobilised in calcium alginate beads and repeatedly used as a whole-cell biocatalyst. The reduction of acetophenone, used as test substrate, was very successful and high yields were detected from immobilised whole cells over repeated biotransformation cycles. The immobilised $H$. volcanii retained stability and high product yields after 1 month of storage at room temperature. This newly developed system offers halophilic enzyme expression in its native environment, high product yield, stability and reusability without the addition of any expensive NADPH/NADH cofactor. This is the first report of whole cell-mediated biocatalysis by the halophilic archaeon $H$. volcanii.
\end{abstract}

Keywords Haloferax volcanii · Biocatalysis · Biotransformation · Whole cell immobilisation · Biocatalyst

\section{Introduction}

Enzymes serve as excellent catalysts due to their ability to catalyse reactions with high enantioselectivity and regioselectivity under environmentally benign conditions (Schmid et al. 2001; Sheldon and Woodley 2018). Due to rapid development of microbial strain engineering and directed evolution, biocatalysis has gained importance in the production of pharmaceutical and agrochemical compounds (Arnold 2018; Bornscheuer et al. 2012; de Carvalho 2017; Schoemaker et al. 2003; Yadav et al. 2012). From an economical and environmental point of view, biocatalysis eliminates

F. Paradisi

francesca.paradisi@nottingham.ac.uk

T. Allers

thorsten.allers@nottingham.ac.uk

1 School of Life Sciences, Queens Medical Centre, University of Nottingham, Nottingham NG7 2UH, UK

2 School of Chemistry, University Park, University of Nottingham, Nottingham NG7 2RD, UK the need for blocking and deblocking steps involved in enantioand regioselective organic synthesis, and the use of fossil fuels needed for achieving high temperature and pressure conditions. Enzymes from extremophiles have the advantage that they are functional in the presence of organic solvents, high temperatures and high salt concentrations (Demirjian et al. 2001). Haloferax volcanii is an extremely halophilic archaeon with its origin in the Dead Sea (Mullakhanbhai and Larsen 1975). It is the organism of choice for haloarchaeal genetics due to the availability of extensive genetic tools (Allers 2010; Allers and Mevarech 2005; Allers et al. 2004). It is easily culturable and has simple laboratory growth condition (aerobic and $45^{\circ} \mathrm{C}$ ). It encodes highly salt and organic solvent-tolerant enzymes such as alcohol dehydrogenase (HvADH2) (Alsafadi and Paradisi 2013). Purified HvADH2 has an unusually broad substrate scope and it catalyses the production of industrially valuable chiral alcohols in the presence of NADPH/NADH cofactor (Fig. 1) (Alsafadi et al. 2017; Timpson et al. 2013).

Industrial application of whole cells for biocatalysis has multiple advantages over purified enzymes. Firstly, whole cell biocatalysts are readily and inexpensively prepared, eliminating the need to purify enzymes (Ishige et al. 2005). Secondly, 
Fig. 1 Bioconversion of acetophenone to 1-phenylethanol catalysed by $H v \mathrm{ADH} 2$. In the presence of NADPH/NADH cofactor, acetophenone is reduced to 1-phenylethol by the activity of $\mathrm{HvADH} 2$ enzyme<smiles>CC(=O)c1ccccc1</smiles>

Acetophenone

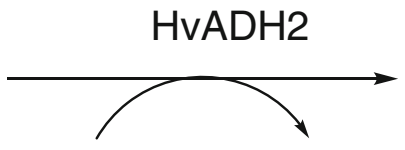

$\mathrm{NAD}(\mathrm{P}) \mathrm{H} \quad \mathrm{NAD}(\mathrm{P})^{+}$<smiles>C[C@H](O)c1ccccc1</smiles>

1-Phenylethanol addition of stoichiometric amounts of expensive cofactor such as NADPH/NADH is not necessary since whole cells can regenerate cofactors in situ (Devaux-Basseguy et al. 1997; Wachtmeister and Rother 2016). Thirdly, enzyme stability is increased due to protection offered by microbial whole cell compartments, and there is ample scope for repeated uses in subsequent processes (de Carvalho 2017; Ishige et al. 2005; Lin and Tao 2017). For these reasons, whole cells are considered as the cheapest form of catalyst for bioconversion (Tufvesson et al. 2011). Immobilisation of microbial whole cells has been used extensively for production of useful chemicals via biotransformation (Chibata 1979; Gotovtsev et al. 2015; Gungormusler-Yilmaz et al. 2016; Zhu 2007) since it eases microbial handling, provides high cell density and most importantly improves operational stability and reusability (Bickerstaff 1997).

Halophilic proteins typically have many acidic residues on the protein surface to make them soluble in high salt environments (Danson and Hough 1997; Mevarech et al. 2000). This can pose problems for heterologous expression of halophilic enzymes in biotechnologically attractive $E$. coli host cells (Lin and Tao 2017; Zhao et al. 2014), since halophilic proteins aggregate and misfold in low ionic environment. Where halophilic proteins have been expressed in E. coli, solubilisation and refolding of insoluble proteins from inclusion bodies has been carried out in a hypersaline environment (Cendrin et al. 1993; Connaris et al. 1999). However, this approach is not universally effective as many enzymes remain inactive (Timpson et al. 2012). Therefore, it is preferable to use a halophilic system to ensure high enzyme expression in their native environment. Such halophilic systems minimise contamination, as other microbes are not able to tolerate the molar salt concentrations. By harnessing the power of microbial engineering and whole cell biocatalysis, we have engineered a halophilic system using immobilised $H$. volcanii whole cells capable of efficient biotransformation through the overexpressed $\mathrm{HvADH} 2$ enzyme activity without the addition of expensive NADPH/NADH cofactor.

\section{Materials and methods}

\section{Reagents, strains and growth conditions}

All chemicals and reagents were purchased from SigmaAldrich (UK) unless otherwise stated. Restriction enzymes and DNA ligases were bought from New England Biolabs (USA). H. volcanii strains were grown at $45^{\circ} \mathrm{C}$ on casamino acid $(H v-\mathrm{Ca})$ agar or complete $(\mathrm{Hv}-\mathrm{YPC})$ agar, and in $\mathrm{Hv}$ YPC broth, and growth media and $18 \%$ salt water were prepared as described previously (Allers et al. 2004). $2 \times \mathrm{YPC}^{+}$ broth was prepared using $10 \mathrm{~g} / \mathrm{L}$ yeast extract, $2 \mathrm{~g} / \mathrm{L}$ casamino acid, $2 \mathrm{mM} \mathrm{K}_{2} \mathrm{HPO}_{4} / \mathrm{KH}_{2} \mathrm{PO}_{4}$ at $\mathrm{pH} 7.5,5 \mathrm{mM} \mathrm{NH} \mathrm{Cl}_{4}$ and $0.5 \%(v / v)$ lactate (Strillinger et al. 2016). All H. volcanii strains are derivatives of H1325 (Timpson et al. 2013), the genotype of H1325 is $\triangle p y r E 2 \triangle h d r B$ Nph-pitA $\triangle m r r$ $\Delta a d h 2 \Delta a d h 1$.

\section{Construction of expression plasmid pTA1992 containing p.syn promoter}

BstBI and NdeI digested pTA1392 was gel purified using gel purification kit (MACHEREY-NAGEL, Germany). Oligonucleotides O247 (Sense, p.synF- CGAGAATC GAAACGCTTATAAGTGCCCCCCGGCTAGAGAGAT) and 0508 (Antisense, p.synR2-TAATCTCTCTAGCC GGGGGGCACTTATAAGCGTTTCGATTCT) were hybridised to generate the p.syn promoter DNA with ClaI and NdeI-compatible ends. Oligo hybridisation was performed in an Eppendorf tube containing $20 \mu \mathrm{l}$ of each oligo $(10 \mu \mathrm{M}), 10 \mu \mathrm{l}$ of NEB Buffer 2 and $50 \mu \mathrm{ld} \mathrm{d}_{2} \mathrm{O}$ at boiling temperature and cooling afterwards. Bst $\mathrm{BI}$ and $N d e \mathrm{I}$ digested pTA1392 and hybridised oligos were ligated and transformed into E.coli XL-1 Blue by electroporation. Following plasmid extraction (Maxiprep, MACHEREY-NAGEL, Germany) integration of p.syn promoter was verified using two sequencing primers (O363: TTAAGTTGGGTAACGCCAGGG) and (O919: AATTCGATATCTCACTTCTCGAACTGCGGGTG CGACCAGCTAGCTGGGGCGCCA). The resulting plasmid was designated pTA1992.

\section{Construction of expression plasmid pTA2035-adh2}

A total of $1050 \mathrm{bp}$ long adh2 (HVO_B0071) was PCR amplified from the pTA1205 plasmid (Timpson et al. 2013) using primers $\mathrm{O} 757$ (adh2F CACAGCGTTCATGAAATC AGCAGTC, BspHI cut site) and 0758 (adh2R, GTCTGGATCCGGGTGTGTCTTACTCG, BamHI cut site). PCR amplification was performed using the NEB Q5 $\mathbb{R}$ Hot Start High Fidelity DNA Polymerase. adh2 was cloned into Pci and BamHI digested pTA1992 plasmid using BspHI 
and $P c i$ compatible ends. PCR reactions were purified using PCR purification kit (MACHEREY-NAGEL, Germany) and were digested with BamHI-HF and BspHI. Plasmid vector pTA1992 was digested with BamHI-HF and PciI. Ligation with T4 Ligase was followed by transformation as above. Primers O245 (HEXTF - GCGCGTAATACGACTCACTA TAGGG) and O47 (PBSR2 - CGCGCAATTAACCC TCACTAAAG) were used for sequencing confirmation and resulting plasmid was designated pTA2035.

\section{Construction of $H$. volcanii strains}

All plasmid transformations into $H$. volcanii were performed as described (Allers et al. 2004). pTA2035 was transformed into the H1325 (Timpson et al. 2013) to generate strain H3924 ( $\Delta$ pyrE2 $\Delta$ hdrB Nph-pitA $\Delta m r r \Delta a d h 2 \Delta a d h 1)$ \{p.syn::histag-adh $2+$ pyrE $2+$ hdrB +$\}$. Empty vector control strain was generated by transforming pTA1992 into H1325 to generate H3925 ( $\triangle$ pyrE2 $\Delta$ hdrB Nph-pitA $\Delta m r r$ Aadh2 $\Delta a d h 1$ ) \{p.syn::his-tag pyrE2 + hdrB+\}.

\section{Purification and enzyme activity determination of $\mathrm{HVADH} 2$}

$\mathrm{H} 3924$ broth culture $(330 \mathrm{ml})$ was grown up to an $\mathrm{OD}_{650 \mathrm{~nm}}$ of 1.0. The cell pellet was resuspended in $7 \mathrm{ml}$ of Buffer $\mathrm{A}$ (20 mM HEPES at pH 7.5, $2 \mathrm{M} \mathrm{NaCl}$, in $\mathrm{dH}_{2} \mathrm{O}$ ) with $1 \times$ EDTA-free SigmaFast protease inhibitor cocktail and was lysed by sonication. Lysate was sequentially filtered through $0.8 \mu \mathrm{m}, 0.45 \mu \mathrm{m}$ and $0.2 \mu \mathrm{m}$ filters. A $0.5 \mathrm{ml}$ of $0.2 \mathrm{M} \mathrm{NiSO}_{4^{-}}$ equilibriated IMAC Sepharose 6 Fast Flow beads were added to the cleared lysate and incubated shaking at $4{ }^{\circ} \mathrm{C}$ for $1 \mathrm{~h}$. After loading a Bio-Rad Poly-Prep gravity column, the beads were washed twice using Buffer A $+1 \mathrm{mM} \mathrm{PMSF}$ at $4{ }^{\circ} \mathrm{C}$, and protein was eluted in $2 \mathrm{ml}$ of Buffer $\mathrm{A}+100 \mathrm{mM}$ Imidazole followed by $2 \mathrm{ml}$ Buffer A $+200 \mathrm{mM}$ Imidazole. Both elutions were combined and concentrated in $2 \mathrm{M} \mathrm{KCl}, 50 \mathrm{mM}$ Glycine/KOH at $\mathrm{pH} 8$ in a Vivaspin ${ }^{\circledR} 20$ column (Sartorius, Germany). Protein concentration was determined using a Pierce $^{\mathrm{TM}}$ BCA Protein Assay Kit (Thermo Scientific, UK).

$H v \mathrm{ADH} 2$ activity was determined by measuring NADPH produced at $340 \mathrm{~nm}$ in intervals of $1 \mathrm{~min}$ for $20 \mathrm{~min}$ at $45^{\circ} \mathrm{C}$ using an EPOCH 2 microplate reader (BioTek). Assay was performed in a total volume of $200 \mu \mathrm{l}$ in 96 Well Clear Flat Bottom UV Transparent Microplate (Corning®, 3635). Reaction mix contained $10 \mu$ of purified $H v A D H 2$ enzyme, $20 \mu \mathrm{l}$ of ethanol, $2 \mu \mathrm{l}$ of $1 \mathrm{mM} \mathrm{NADP}{ }^{+}, 168 \mu \mathrm{l}$ of $4 \mathrm{M} \mathrm{KCl}$ and $50 \mathrm{mM}$ Glycine/KOH at $\mathrm{pH} 10$.

\section{Immobilisation of $H$. volcanii within alginate beads}

An H. volcanii $380 \mathrm{ml}$ culture ( $3.5 \mathrm{~g}$ pellet) grown up to an $\mathrm{OD}_{650 \mathrm{~nm}}$ of 1.0-1.2 and pelleted. In a sterile $50 \mathrm{ml}$ Duran bottle, the cell pellet was gently resuspended in $12 \mathrm{ml} \mathrm{YPC}$ broth and mixed with $50 \mathrm{ml}$ of $4 \%$ sodium alginate (SIGMA 71238) solution in $\mathrm{dH}_{2} \mathrm{O}$ using a sterile magnetic stirrer. After

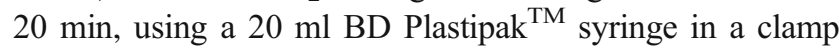
stand, the $H$. volcanii-Na-alginate mixture was added dropwise to $100 \mathrm{ml}$ of $1.5 \% \mathrm{CaCl}_{2}\left(\right.$ in $\mathrm{H}_{2} \mathrm{O}$ ) solution. The distance between the syringe tip and surface of $\mathrm{CaCl}_{2}$ solution was $13 \mathrm{~cm}$. Beads were left to settle for $30 \mathrm{~min}$ at room temperature. $H$. volcanii beads were separated from the bulk $\mathrm{CaCl}_{2}$ solution using a sterile strainer and washed twice with $18 \%$ salt water before biotransformation.

\section{Biotransformation protocol}

For each immobilised $H$. volcanii strain, $20 \mathrm{~g}$ of weighed beads were used for biotransformation. After two washes with $18 \%$ salt water, beads were added to a sterile $250 \mathrm{ml}$ Duran conical flask with $5 \mathrm{mM}$ acetophenone substrate in $50 \mathrm{ml} \mathrm{YPC}$ broth $+4 \%$ glucose unless otherwise stated. Flasks were shaken at $150 \mathrm{rpm}$ agitation for $24 \mathrm{~h}$ in a $45^{\circ} \mathrm{C}$ water bath. After 24 h, $2 \mathrm{ml}$ of supernatant was centrifuged at $18000 \mathrm{RCF}$ for 10 min. Product was measured by HPLC by adding $50 \mu \mathrm{l}$ of supernatant into a HPLC vial with $475 \mu \mathrm{l}$ of HPLC grade acetonitrile and $475 \mu \mathrm{l} 0.2 \% \mathrm{HCl}$ in $\mathrm{dH}_{2} \mathrm{O}$. Diameter of the beads before starting and after biotransformation for 12 successive cycles was measured using Vernier callipers.

\section{HPLC protocol}

HPLC was performed using a reverse phase XBridge $\mathrm{C} 18,3.5$ $\mu \mathrm{m}, 2.1 \mathrm{~mm} \times 30 \mathrm{~mm}$ column with a flow rate of $0.8 \mathrm{~mL} / \mathrm{min}$ at $40{ }^{\circ} \mathrm{C}$ temperature. Samples were analysed using a gradient of two solutions A $(0.01 \%$ ammonia acid in water) and B (acetonitrile). Gradient program was used as follows; at $0 \min 95 \% \mathrm{~A}, 5 \% \mathrm{~B}$, at $3 \min 5 \% \mathrm{~A}$ and $95 \% \mathrm{~B}$, at $3.10 \mathrm{~min} 0 \% \mathrm{~A}, 100 \% \mathrm{~B}$, at $3.51 \mathrm{~min} 95 \% \mathrm{~A}, 5 \% \mathrm{~B}$ and at 4.5 min $95 \%$ A, $5 \%$ B. Retention time for the product (1phenylethanol) and substrate (acetophenone) was determined as $1.7 \mathrm{~min}$ and $2.2 \mathrm{~min}$ respectively. UV absorption was measured at $210 \mathrm{~nm}$. Amount of product was quantified using a standard curve for 1-phenylethanol sample gradient.

\section{Results}

\section{Construction of a constitutive gene expression system in $H$. volcanii}

Existing gene expression systems for $H$. volcanii are based on a tryptophan inducible promoter (p.tna) (Allers 2010). For example, the $H v \mathrm{ADH} 2$ overexpression strain $\mathrm{H} 1332$ requires induction with $\mathrm{mM}$ concentrations of tryptophan to activate adh2 expression (Timpson et al. 2013). To alleviate the need 
for tryptophan supplementation in batch cultures, a $H$. volcanii strain was generated that expresses adh 2 constitutively. p.syn is $43 \mathrm{bp}$ long strong synthetic promoter based on the $H$. volcanii consensus tRNA promoter sequence (Large et al. 2007). A plasmid vector pTA1992 for constitutive gene expression was created by replacing the tryptophan inducible promoter (p.tna) of pTA1392 with the constitutive p.syn promoter (Fig. 2a). The HvADH2 overexpression plasmid pTA2035 was generated by cloning the adh 2 under the control of the p.syn (Fig. 2b), and the H. volcanii strain H3924 was generated by transforming the pTA2035 plasmid into the H1325 ( $\Delta a d h 2 \Delta a d h 1)$. It was essential to use $a d h$-deleted strain as previous work had shown endogenous $\mathrm{ADH}$ form a complex with recombinant ADH (Timpson et al. 2013). The empty vector pTA1992 was transformed into H1325 to generate the background strain H3925 as a control for biotransformation.

\section{HvADH2 protein expression and enzymatic activity in $\mathrm{H} 3924$}

To confirm $H v A D H 2$ expression and enzymatic activity in $\mathrm{H} 3924$, histidine-tagged $\mathrm{HvADH} 2$ was purified using nickel-based affinity chromatography. SDS-PAGE gel electrophoresis revealed a band corresponding to the

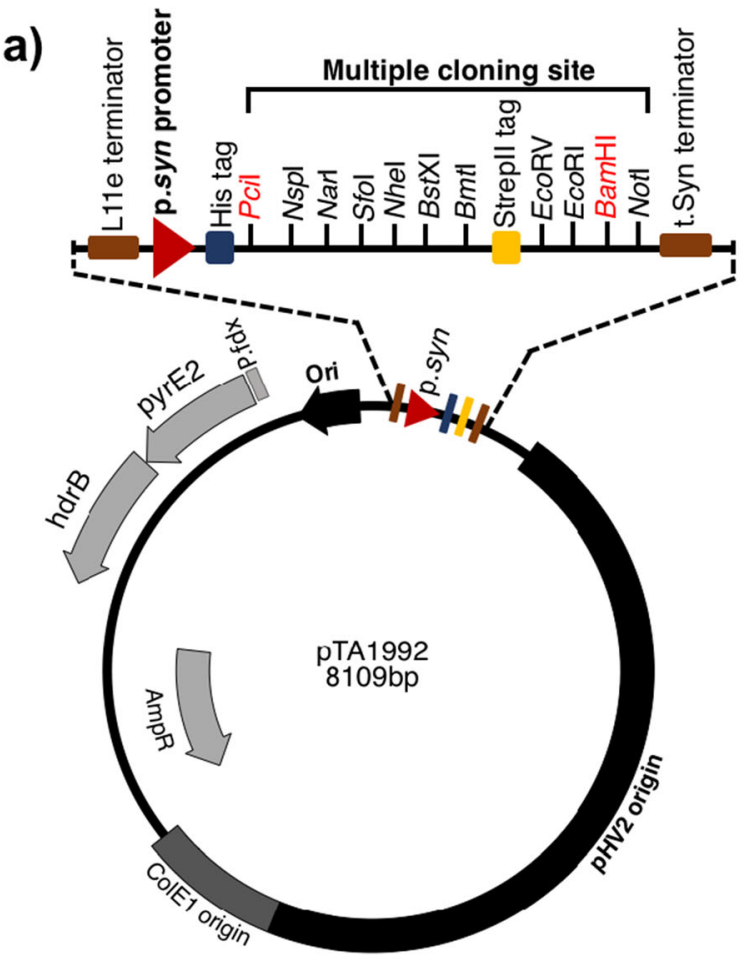

Fig. 2 Map of constitutive gene expression system in $H$. volcanii. a pTA1992. The p.syn promoter is used for constitutive expression of His (Histidine) tagged proteins in H. volcanii. A multiple cloning site is located after His tag, and is flanked by L11e and t.Syn terminators to prevent read-through transcription. pTA1992 was transformed into subunit molecular weight of $37.8 \mathrm{kDa}$ as expected (lane 2, Fig. 3a) and high levels of $\mathrm{HvADH} 2$ protein production (mean $4.74 \mathrm{mg} / \mathrm{ml}$ ) and specific activity (mean $3.7 \mathrm{U} / \mathrm{mg}$ of protein) were detected in $\mathrm{H} 3924$ (Fig. 3b).

\section{Immobilisation of $H$. volcanii within calcium alginate beads}

The naturally occurring marine polymer alginate is the most widely used encapsulation agent for cell immobilisation (Strand et al. 2004). Alginate is a linear binary polysaccharide composed of 1-4 linked $\beta$-D-mannuronic acid and $\alpha$-L-guluronic acid residues (Haug and Larsen 1966; Lee and Mooney 2012). When a mixture of cell suspension and alginate is dropped into a solution of divalent cations $\left(\mathrm{Ca}^{2+}, \mathrm{Ba}^{2+}, \mathrm{Sr}^{2+}\right)$, a porous spherical gel matrix is formed instantly through ionic crosslinking between cation and anionic guluronic acid residues of alginate (Melvik and Dornish 2004). The resulting matrix in the form of a bead possesses biotechnologically attractive properties such as instant gel formation, non-toxicity, high porosity and an inert aqueous and heat-stable matrix (Gombotz and Wee 1998; Melvik and Dornish 2004). Calcium alginate beads have

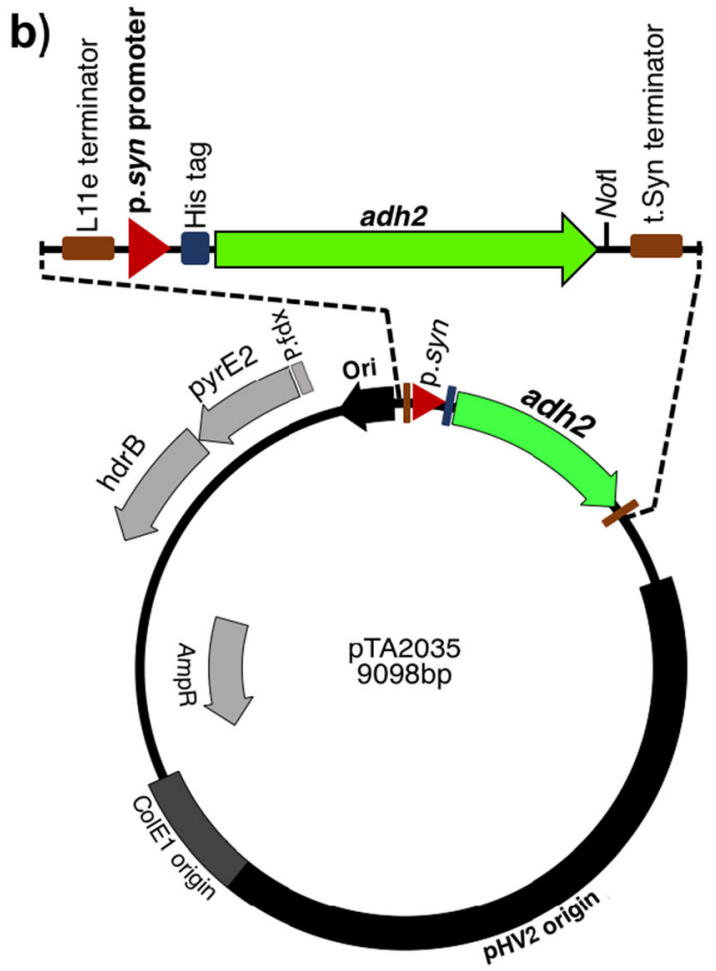

H1325 to generate H3925 to serve as empty vector control for biotransformation, b pTA2035. The adh2 (HVO_B0071, 1050 bp) gene was inserted in pTA1992 under the control of the constitutive p.syn promoter. pTA2035 was transformed into H1325 to generate H3924 for HvADH2 expression 


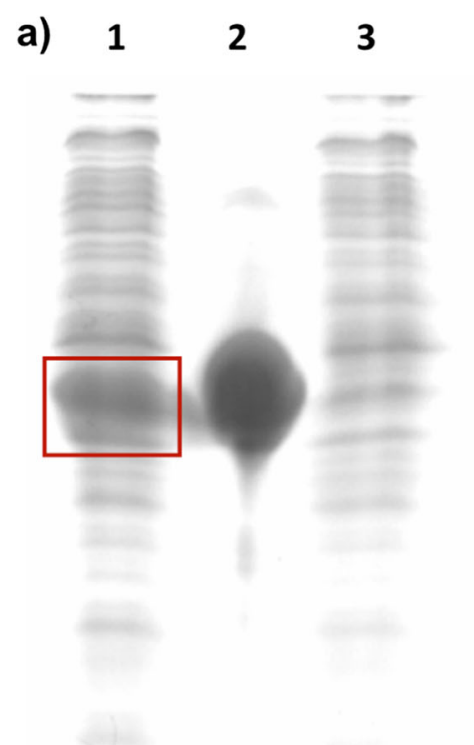

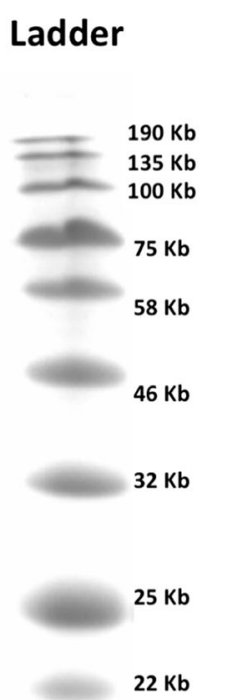

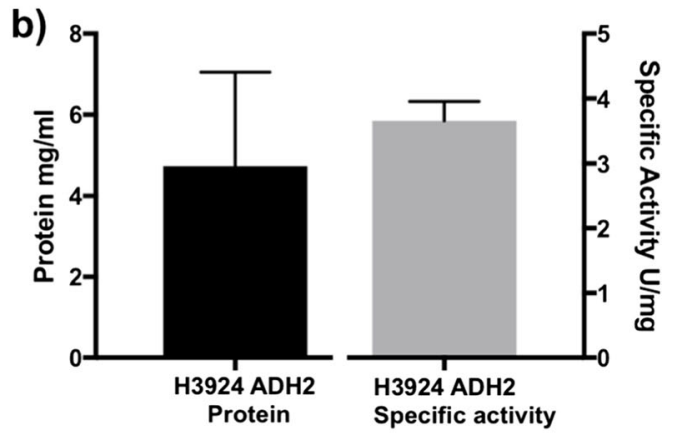

Fig. $3 H v \mathrm{ADH} 2$ expression and enzymatic activity from H3924. a SDSPAGE confirmation of high $H v A D H 2$ expression from $\mathrm{H} 3924$, lane 1, $\mathrm{H} 3924$ His- $H v \mathrm{ADH} 2$ cell lysate $(H v \mathrm{ADH} 2$ indicated in red box); lane 2,

been successfully used in biocatalysis to produce 1phenylethanol from Hansenula capsulata (Hasegawa et al. 1998), Rhodotorula glutinis (Kurbanoglu et al. 2010) and Pichia capsulata (Illeová et al. 2015). The HvADH2 expressing H3924 strain was immobilised within the calcium alginate beads for 1-phenylethanol production (Fig. 4a) and entrapment of $H$. volcanii was confirmed by distinctive pink carotenoid pigment produced by this organism (Fig. $4 \mathrm{~b}$ and $\mathrm{c}$ ). purified HvADH2 (37.8 kDa); lane 3, H3925 cell lysate, b purified $H v \mathrm{ADH} 2$ protein concentration and enzyme specific activity, mean \pm $\mathrm{SD}, n=5$

\section{Effect of substrate concentration, culture agitation speed, temperature, nutrient media and gene expression system on product yield}

The optimal conditions for maximal product yield were determined. Alongside the regular YPC broth used for culturing $H$. volcanii, the impact of different nutrient sources such as fructose, lactate, sucrose and glucose was investigated. In addition, the $2 \times \mathrm{YPC}^{+}$broth was used to study its impact as it

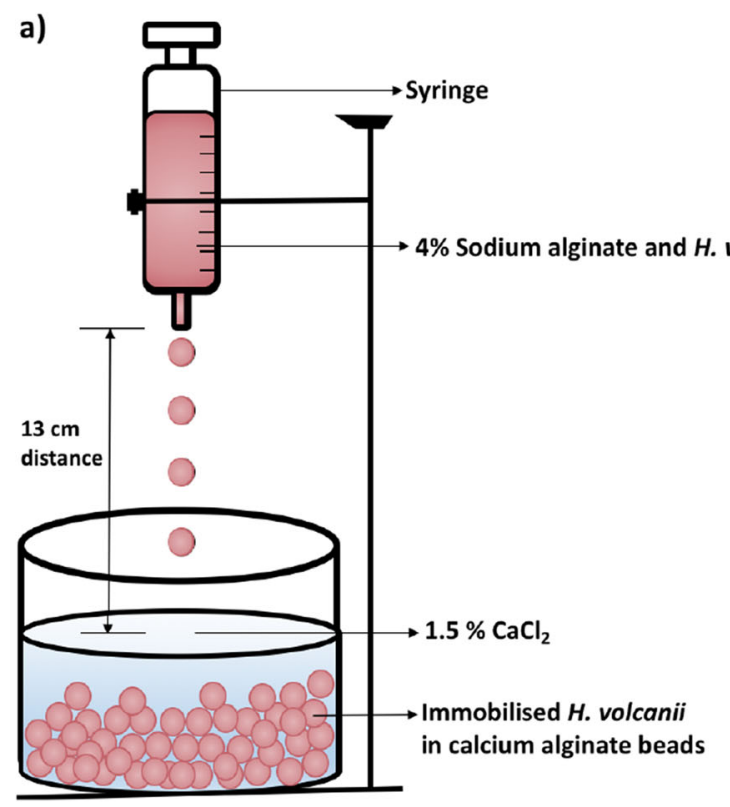

Fig. 4 Procedure for immobilising $H$. volcanii within calcium alginate beads. a $H$. volcanii cell pellet resuspended in YPC broth was mixed gently with $4 \%$ sodium alginate solution (in $\mathrm{dH}_{2} \mathrm{O}$ ) using a magnetic stirrer. Using a BD Plastipak ${ }^{\mathrm{TM}}$ syringe, the mixture was added

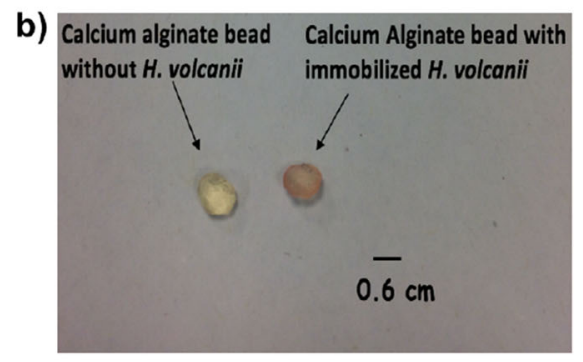

c)

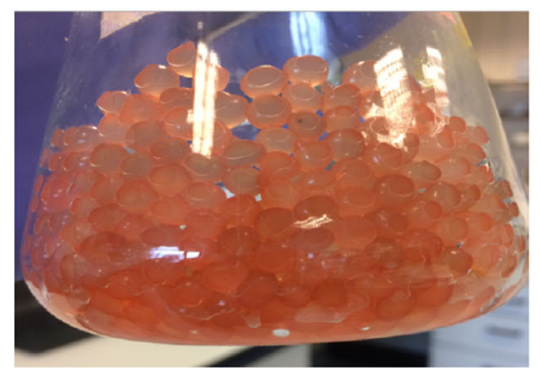

dropwise into $1.5 \% \mathrm{CaCl}_{2}$ solution to form beads, $\mathbf{b}$ and $\mathbf{c}$ formation of pink beads confirmed entrapment of $H$. volcanii within calcium alginate beads, the distinctive colour is due to presence of high carotenoid pigment 
contains added nutrients for rapid growth of $H$. volcanii (Strillinger et al. 2016). After biotransformation in the presence of $5 \mathrm{mM}$ acetophenone substrate at $45^{\circ} \mathrm{C}$ for $24 \mathrm{~h}$ using $20 \mathrm{~g}$ of calcium alginate beads with immobilised $H$. volcanii, $57 \%$ yield was detected with YPC broth (Fig. 5a). Supplementation of YPC $+4 \%$ fructose resulted in a reduction in yield to $47 \%$. Compared to YPC, supplementation with $4 \%$ lactate and $4 \%$ sucrose resulted in increased yield to $66 \%$ and $64 \%$ respectively. Maximal 1-phenylethanol production was achieved with $2 \times \mathrm{YPC}^{+}(95 \%)$ and $\mathrm{YPC}+4 \%$ glucose $(98 \%)$, which is almost double the yield found with YPC broth only condition.

To determine the optimum temperature for biotransformation, reaction was performed at $25^{\circ} \mathrm{C}$ and $45^{\circ} \mathrm{C}$. Growth at 45 ${ }^{\circ} \mathrm{C}$ yields three times more product compared to the reaction conducted at $25^{\circ} \mathrm{C}(97.5 \%$ vs $27 \%)$ (Fig. 5 b). Agitation speed of the batch culture was also investigated. A comparative analysis of yield at $50 \mathrm{rpm}, 100 \mathrm{rpm}, 150 \mathrm{rpm}$ and $200 \mathrm{rpm}$ was performed (Fig. 5c). Lowest yield of $47 \%$ was found at 50 $\mathrm{rpm}$. Increased yield of $76.5 \%$ was found at $100 \mathrm{rpm}$ but
Fig. 5 Characterisation of conditions for maximal product yield. a Nutrient broth.

Biotransformation reactions were performed in YPC, YPC $+4 \%$ fructose, YPC $+4 \%$ lactate, YPC $+4 \%$ sucrose, $2 \times \mathrm{YPC}^{+}, \mathrm{YPC}+$ $4 \%$ glucose, $n=3$. b Temperature. Biotransformation was performed at $25^{\circ} \mathrm{C}$ and $45^{\circ} \mathrm{C}, n=3$. c Agitation speed. Beads in broth were agitated at $50 \mathrm{rpm}, 100 \mathrm{rpm}$, $150 \mathrm{rpm}$ and $200 \mathrm{rpm}$ speed, $n=$ 5. d Substrate concentration. $10 \mathrm{mM}$ and $50 \mathrm{mM}$ acetophenone substrate was added to the broth, $n=3$. e Inducible vs constitutive gene expression system.

Biotransformation was performed using the inducible $(+5 \mathrm{mM}$ tryptophan) adh2 strain $\mathrm{H} 1332$ and the constitutive $a d h 2$ strain H3924, $n=3$, mean $\pm \mathrm{SD}$ a)

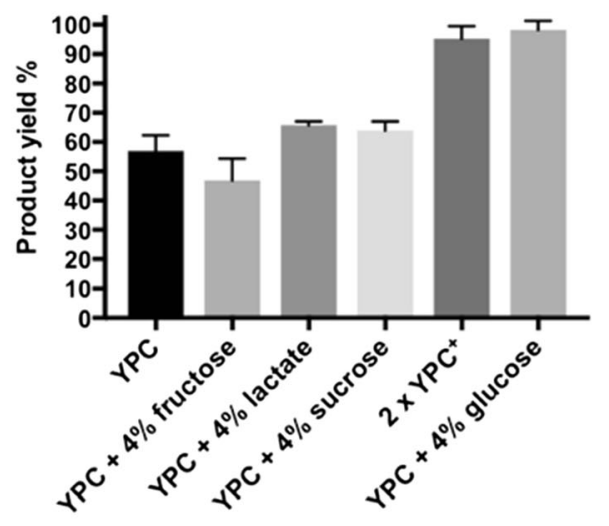

c)

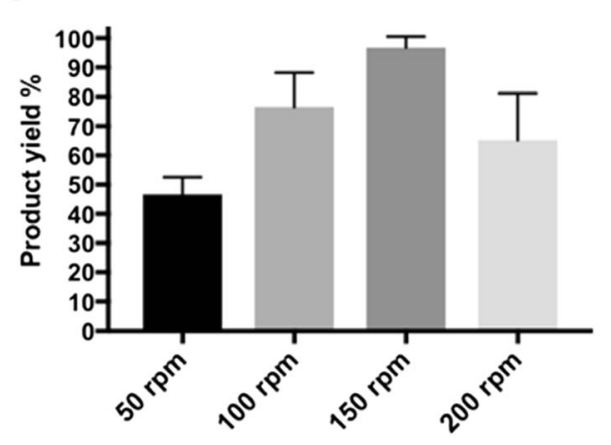

b)

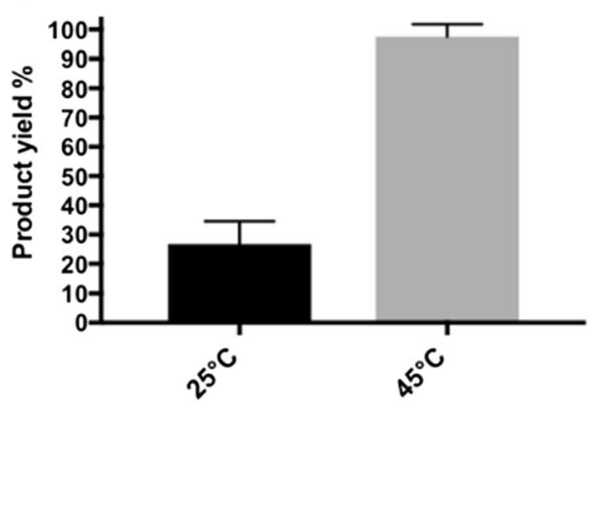

d)

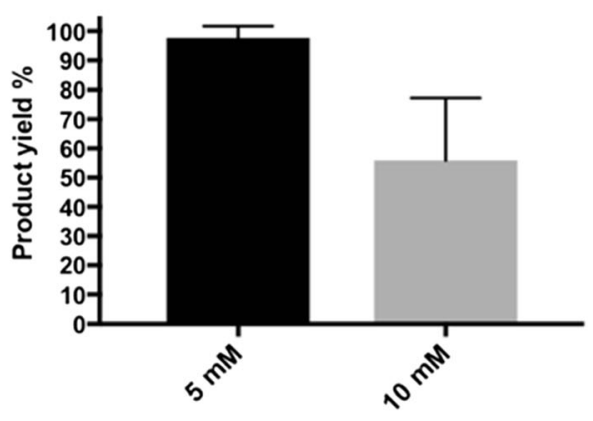

e)

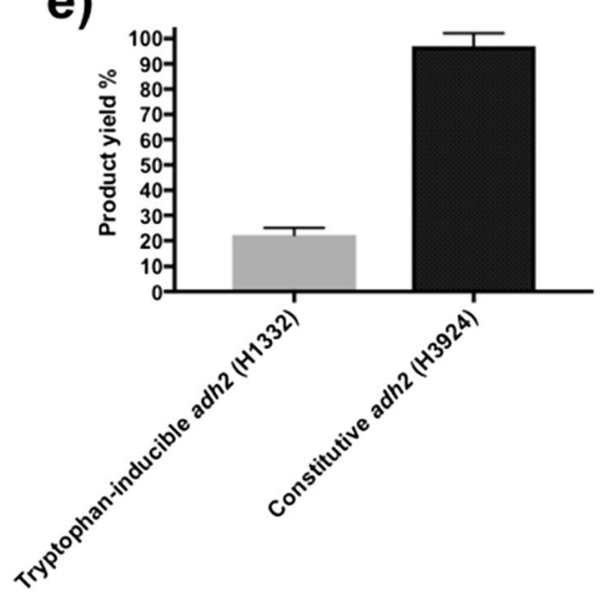


maximal product yield of $97 \%$ was found at $150 \mathrm{rpm}$. Interestingly, a lower yield of $65 \%$ was detected with the highest speed agitation at $200 \mathrm{rpm}$. Two different concentrations of acetophenone substrate were compared (Fig. 5d). A yield of $55 \%$ was found with $10 \mathrm{mM}$ substrate, which is nearly half of $98 \%$ yield found with the $5 \mathrm{mM}$ substrate. Finally, the effect of inducible versus constitutive $a d h 2$ gene expression was tested. Three times more yield was detected from the new constitutively expressing adh2 strain H3924 (97\%) compared to the published tryptophan-induced $a d h 2$ strain H1332 (22\%) (Fig. 5e) (Timpson et al. 2013).

\section{Repeated batch production of 1-phenylethanol by once immobilised $H$. volcanii for 12 successive biotransformation cycles}

The reusability of the system was investigated. Each biotransformation cycle was performed in YPC $+4 \%$ glucose broth using once immobilised $\mathrm{H} 3924$ whole cells in beads at $45^{\circ} \mathrm{C}$ for $24 \mathrm{~h}$ and the broth was sampled for 1-phenylethanol detection by HPLC. This process was continued for 12 successive cycles. High 1-phenylethanol production (yield range 96.4-100\%) was detected over 12 successive cycles (Fig. 6). No background conversion was detected from the immobilised control strain H3925, which contains the empty vector plasmid pTA1992, and from calcium alginate beads without any immobilised $H$. volcanii. Long-term stability was tested by performing biotransformation using calcium alginate beads with immobilised H3924 that had been stored in $18 \%$ salt water solution for a month at room temperature.

\section{- Freshly prepared H3924 (+adh2) beads - 1 month old H3924 (+adh2) beads}

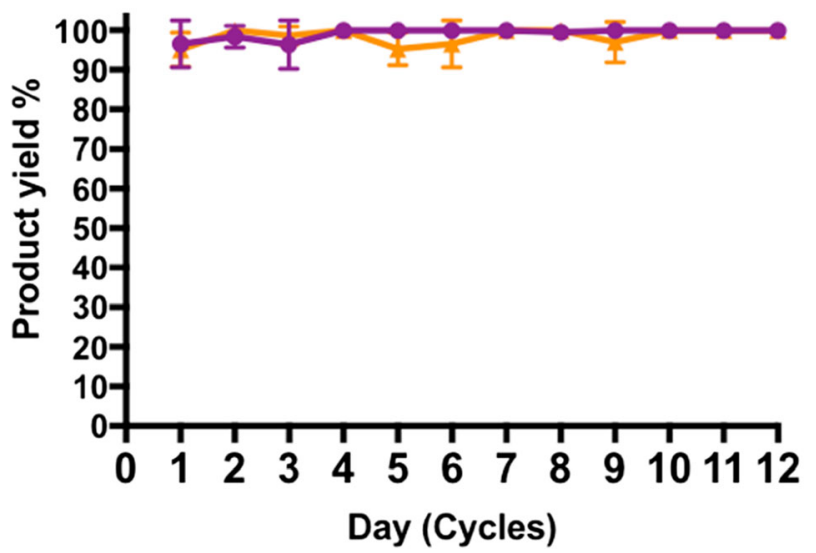

Fig. 6 Repeated batch production of 1-phenylethanol by immobilised $H$. volcanii in calcium alginate beads. Product yield was measured by HPLC each day over a successive period of 12 days (cycles). After 24 $\mathrm{h}$, the entire YPC $+4 \%$ glucose broth containing beads was decanted, beads were washed twice with $18 \%$ salt water and the biotransformation cycle was started again by adding fresh batch of broth supplemented with $5 \mathrm{mM}$ acetophenone substrate. Data represents mean $\pm \mathrm{SD}, n=3$
Repeated batch production of 1-phenylethanol (yield range 95.2-100\%) was detected from these beads over successive 12 cycles (Fig. 6). Alginate bead deformation due to bead softening could lead to loss of cells and thereby affect the long-term stability of the whole cell biocatalyst (Smidsrod and Skjak-Braek 1990). Bead diameter was measured before starting the first biotransformation cycle and after the completion of 12 cycles. Data showed that bead diameters were unaffected after 12 successive cycles (Fig. 7a and b).

\section{Discussion}

This work is the first demonstration of $H$. volcanii whole cellmediated biocatalysis which we exemplified with the reduction of acetophenone to 1-phenylethanol. This system offers halophilic enzyme expression in its native environment, high product yield, reusability and stability. In addition to 1phenylethanol, the system can be adapted to produce other biotechnologically important compounds from $H$. volcanii. This study is a demonstration of how genetic engineering can be combined with whole cell biocatalysis to design customised system for biotechnology.

Immobilisation within calcium alginate beads makes the system operationally stable and reusable for successive biotransformation cycles. Several steps were essential for producing uniform and stable calcium alginate beads in a reproducible manner. Firstly, when preparing the $4 \%$ sodium alginate solution in $\mathrm{dH}_{2} \mathrm{O}$, sodium alginate powder had to be added very slowly into $\mathrm{dH}_{2} \mathrm{O}$ in small quantity using a magnetic stirrer to prevent clump formation. Any clump will affect the extent of cross-linking and the overall alginate bead size, resulting in poor product yield and operational stability. Secondly, use of a magnetic stirrer to mix $H$. volcanii cells with $4 \%$ sodium alginate helps to avoid shear stress on the encapsulated cells and also helps prevent bubble formation in beads. When air bubbles are formed, the alginate bead suspension was left to stand at room temperature for an extra hour to let the bubbles dissolve. Finally, the $H$. volcanii-alginate mixture must be added very slowly in a drop-wise manner into sufficient amount of $1.5 \% \mathrm{CaCl}_{2}$ (in $\mathrm{H}_{2} \mathrm{O}$ ) from a fixed distance (13 cm for this study) to ensure uniform morphology and size of the beads. Any bead partially submerged in $\mathrm{CaCl}_{2}$ would have an irregular shape and poor rigidity, which could lead to the leakage of immobilised $H$. volcanii.

It was imperative to strike a balance between rigidity of alginate matrix and porosity, as substrate and product must be transported across the pores to and from the immobilised cells. In principle, any multivalent cation can act as a gelling ion with negatively charged guluronic acid to form alginate beads. The rigidity of the alginate beads depends on the cation used: $\mathrm{Ba}^{2+}>$ $\mathrm{Sr}^{2+}>\mathrm{Ca}^{2+}>\mathrm{Pb}^{2+}>\mathrm{Cu}^{2+}>\mathrm{Ni}^{2+}>\mathrm{Cd}^{2+}>\mathrm{Zn}^{2+}>\mathrm{Co}^{2+}>\mathrm{Mn}^{2+}$ (Smidsrød 1974; Strand et al. 2004). Since metal ion-mediated 


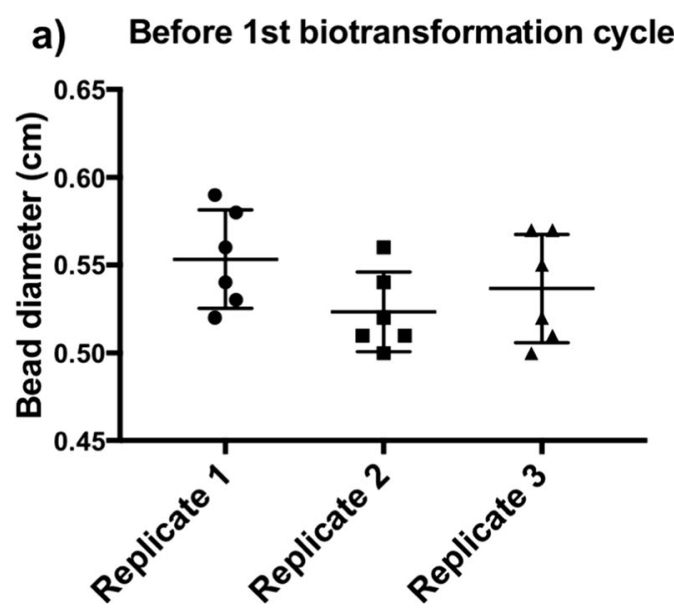

Fig. 7 Calcium alginate bead morphology is unperturbed after 12 successive biotransformation cycles. Six beads with immobilised $H$. volcanii were randomly selected from each biological replicate

toxicity could be a limiting factor for whole cell-mediated biocatalysis, use of $\mathrm{Pb}^{2+}, \mathrm{Cu}^{2+}, \mathrm{Cd}^{2+}, \mathrm{Ni}^{2+}, \mathrm{Zn}^{2+}, \mathrm{Co}^{2+}$ and $\mathrm{Mn}^{2+}$ was ruled out. Use of high concentrations of $\mathrm{Ba}^{2+}$ for gelation could have a negative effect on cells due to the leakage of toxic ions (Mørch etal. 2012). Furthermore beads formed with $\mathrm{Ba}^{2+}$ and $\mathrm{Sr}^{2+}$ are stronger and less porous than beads formed with $\mathrm{Ca}^{2+}$ (Morch etal. 2006; Wideroe and Danielsen 2001), and it would be difficult for substrate to access the immobilised cells in a tightly packed and less porous matrix. $\mathrm{Ca}^{2+}$ immobilisation was used since it is non-toxic and has been widely used for immobilised whole cellmediated biocatalysis. Other desirable attributes for an immobilising agent, such as non-reactivity to substrates and products, resistance to microbial degradation, easy preparation and handling and low cost, were also satisfied by this selection.

In YPC broth only condition, a modest yield of 57\% was found. Apart from YPC + 4\% glucose, similar low yields were found with other supplements such as sucrose, fructose and lactate. The high product yield from YPC $+4 \%$ glucose could have been due to glucose bolstering the redox potential of the cells to regenerate the NADPH/NADH cofactor. This is achieved via the dissimilatory metabolism of glucose acting as substrate for NADPH/NADH production (DevauxBasseguy et al. 1997; Hummel and Gröger 2014). Although ethanol could have been used as an alternative cosubstrate for cofactor regeneration (Alsafadi et al. 2017; Kometani et al. 1995), it could have reacted with acetophenone substrate and would have been toxic for the $H$. volcanii whole cell biocatalyst. Furthermore, glucose can serve as cosubstrate for either NADH- or NADPH-dependent bioreduction under both aerobic and anaerobic conditions, whereas ethanol cannot serve as cosubstrate for NADPH-dependent bioreduction in anaerobic conditions (Kometani et al. 1994). HvADH2 activity is predominantly NADPH-dependent (Timpson et al. 2013). High yield was also seen with $2 \times \mathrm{YPC}^{+}$broth and could have been due to the increased growth of $H$. volcanii,

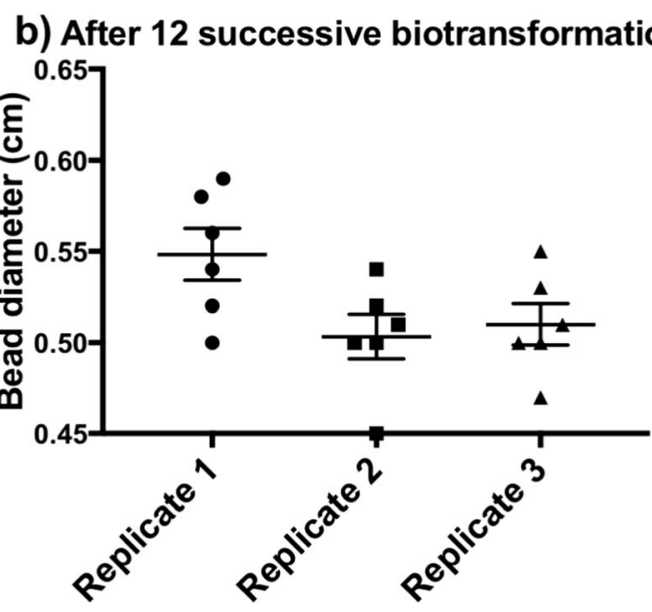

before (a) and after 12 biotransformation cycles (b). Diameter of the beads were measured, mean $\pm \mathrm{SD}, n=6$

since this broth contains additional yeast extract, casamino acid, lactate, $\mathrm{K}_{2} \mathrm{HPO}_{4} / \mathrm{KH}_{2} \mathrm{PO}_{4}$ and $\mathrm{NH}_{4} \mathrm{Cl}$ nutrients (Strillinger et al. 2016). YPC $+4 \%$ glucose broth was chosen as it is more economical than the costs associated with supplementation of the $2 \times \mathrm{YPC}^{+}$broth.

Higher yield at $45^{\circ} \mathrm{C}$ compared to $25^{\circ} \mathrm{C}$ was due to $H$. volcanii growing optimally at $45^{\circ} \mathrm{C}$. This is in keeping with previous whole cell biocatalysis studies where organism's temperature optimum yields the highest 1-phenylethanol product (Homola et al. 2015; Illeová et al. 2015; Kurbanoglu et al. 2010). Lowest yield found at $50 \mathrm{rpm}$ was probably due to slow agitation resulting in insufficient contact between substrate and biocatalyst. Maximal product yield using $H$. volcanii requires effective contact between substrate and biocatalyst, as well as effective aeration of the immobilised cells. To this end, agitation at $150 \mathrm{rpm}$ appeared to provide the right balance required for maximal product yield. We also noticed some debris in the media resulting from bead disintegration with repeated agitation at $200 \mathrm{rpm}$. Multiple explanations could account for a significant drop in product yield to $\sim 50 \%$ with $10 \mathrm{mM}$ substrate (compared to $5 \mathrm{mM}$ substrate). Firstly, excessive substrate $(10 \mathrm{mM})$ might lead to sufficient accumulation of product $(\sim 5 \mathrm{mM})$ that interferes with the reaction, leading to reduced $H v \mathrm{ADH} 2$ activity. A study using yeast Rhodotorula glutinis whole cells reported inhibition of biocatalyst by product accumulation (Valadez-Blanco and Livingston 2009). This problem could be overcome by in situ product removal from the biocatalyst (Freeman et al. 1993). Secondly, excessive substrate (10 $\mathrm{mM}$ ) might be toxic and compromise the performance of the whole cell biocatalyst. Intermittent substrate feeding strategy could be used to overcome this issue (Valadez-Blanco and Livingston 2009).

Existing gene expression systems for $H$. volcanii are based on a tryptophan inducible promoter (p.tna) (Allers 2010). The constitutive expression system developed in this study alleviates the need for any tryptophan supplementation (which may 
result in batch-to-batch variation) and also improves the product yield significantly compared to tryptophan-inducible expression system. Furthermore, repeated supplementation of tryptophan would not be cost effective since it is an expensive amino acid. However, use of this strong constitutive promoter has to be carefully considered when overexpression of the enzyme is toxic for cells.

Our whole cell immobilisation method generated roughly $60 \mathrm{~g}$ of beads from $3.5 \mathrm{~g}$ of $\mathrm{H}$. volcanii cell pellet $(380 \mathrm{ml}$ broth culture), of which $20 \mathrm{~g}$ were used in all biotransformation reactions. Therefore, in this system, $1.1 \mathrm{~g}$ dry weight $(120 \mathrm{ml}$ broth culture) of whole cell biocatalyst had a high product yield range of $96.4-100 \%$ under optimal conditions (in the presence of $5 \mathrm{mM}$ acetophenone substrate after $24 \mathrm{~h}$ ). By comparison, $5 \mathrm{~g}$ of Aspergillus niger whole cell biocatalyst was reported to show a yield range of 53-63\% in the presence of $1 \mathrm{mM}$ acetophenone substrate, after $24 \mathrm{~h}$ (Kurbanoglu et al. 2007). In another study, $500 \mathrm{ml}$ of Yarrowia lipolytica gave a yield range of 48-94\% in the presence of $3.3 \mathrm{mM}$ substrate, after $48 \mathrm{~h}$ (Janeczko et al. 2015). The performance of our whole cell biocatalyst is severalfold greater than the above two studies. Furthermore, we provide evidence for high product yield using whole cell biocatalyst for 12 successive cycles, both from freshly prepared beads as well as beads stored at room temperature for a month. In this system, any 1-phenylethanol detected is solely due to the $H v \mathrm{ADH} 2$ activity from the immobilised $\mathrm{H} 3924$ cells, since there was no background conversion in the control strain H3925, or in alginate beads without any immobilised H. volcanii. The engineered strain H1325 ( $\triangle a$ adh2 $\Delta a d h 1$ $\triangle p y r E 2 \Delta h d r B$ Nph-pitA $\Delta m r r)$ used in this work is depleted of all endogenous ADH activity and bioconversion is detected only when the recombinant $H v \mathrm{ADH} 2$ is expressed.

Unchanged diameters of calcium alginate beads confirmed their stability. It is noteworthy the YPC broth contains $2.46 \mathrm{M} \mathrm{Na}^{+}, 0.18 \mathrm{M} \mathrm{Mg}^{2+}$ and $3 \mathrm{mM} \mathrm{Ca}^{2+}$ of which $\mathrm{Na}^{+}$and $\mathrm{Mg}^{2+}$ have been referred to as anti-gelling cations for alginate beads (Melvik and Dornish 2004). However, several studies indicate that $\mathrm{Mg}^{2+}$ acts as a cross-linker for alginate bead formation (Topuz et al. 2012; Vicini et al. 2017). Multiple explanations could account for alginate beads in this system withstanding molar concentrations of anti-gelling cations. Firstly, high alginate concentration (4\%) meant there was abundance of guluronic acid residues which make gels stable in the presence of monovalent cations such as $\mathrm{Na}^{+}$(Martinsen et al. 1989). High guluronic acid content also transforms $\mathrm{Mg}^{2+}$ into a gelling cation (Topuz et al. 2012). Secondly, the presence of $3 \mathrm{mM} \mathrm{Ca}^{2+}$ in the YPC broth would have contributed to the stability of the calcium alginate beads, as supplementation of $\mathrm{mM}$ calcium is essential for the maintenance of alginate beads (Strand et al. 2004). A $3 \mathrm{mM} \mathrm{Ca}^{2+}$ is also present in $18 \%$ salt water used in bead washing steps, this is necessary as $H$. volcanii cells lyse in a low salt environment.
This system can easily be scaled up by packing alginate beads with immobilised $H$. volcanii cells into a controlled stirred tank bioreactor (Strillinger et al. 2016). Instead of batch culture condition, it can also be used in a continuous flow system for increased productivity (Porta et al. 2016; Tamborini et al. 2018; Tamborini et al. 2013). When compared with other extremophiles such as thermophiles, the biotechnological potential of halophiles has been less explored. Production of $\beta$-carotene by green algae Dunaliella salina and ectoine, an enzyme immobiliser used in cosmetic products by Halomonas elongata represent the few examples of successful application of halophiles in industrial biotechnology (Oren 2010). This could be due to halophiles such as $H$. volcanii being mechanically fragile and prone to lysis with decreased salt concentrations. This development of this system of immobilised cells in alginate beads circumvents some of these issues and harnesses the biotechnological potential of halophiles to produce valuable biomolecules.

Acknowledgements We thank David Roura Padrosa and Dr Martina Contente for useful discussions on HPLC and Laura Mitchell for assistance with media preparation for $H$. volcanii.

Author contributions RH, FP and TA conceived the study. RH performed the experiments and carried out the analysis. RH, FP and TA wrote the manuscript.

Funding This work was supported by the Biotechnology and Biological Sciences Research Council (BBSRC) (grant number BB/P002536/1). The funders had no role in study design, data collection and interpretation, or the decision to submit the work for publication.

\section{Compliance with ethical standards}

Competing interests The authors declare that there are no competing interests.

Ethical approval This is not applicable since the work does not involve any study with human participants or animals.

Open Access This article is distributed under the terms of the Creative Commons Attribution 4.0 International License (http:// creativecommons.org/licenses/by/4.0/), which permits unrestricted use, distribution, and reproduction in any medium, provided you give appropriate credit to the original author(s) and the source, provide a link to the Creative Commons license, and indicate if changes were made.

\section{References}

Allers T (2010) Overexpression and purification of halophilic proteins in Haloferax volcanii. Bioeng Bugs 1(4):288-290. https://doi.org/10. 4161/bbug.1.4.11794

Allers T, Mevarech M (2005) Archaeal genetics - the third way. Nat Rev Genet 6(1):58-73. https://doi.org/10.1038/nrg1504

Allers T, Ngo H-P, Mevarech M, Lloyd RG (2004) Development of additional selectable markers for the halophilic archaeon 
Haloferax volcanii based on the leuB and trpagenes. Appl Environ Microbiol 70(2):943-953

Alsafadi D, Paradisi F (2013) Effect of organic solvents on the activity and stability of halophilic alcohol dehydrogenase (ADH2) from Haloferax volcanii. Extremophiles 17(1):115-122. https://doi.org/ 10.1007/s00792-012-0498-0

Alsafadi D, Alsalman S, Paradisi F (2017) Extreme halophilic alcohol dehydrogenase mediated highly efficient syntheses of enantiopure aromatic alcohols. Org Biomol Chem 15(43):9169-9175. https:// doi.org/10.1039/c7ob02299a

Arnold FH (2018) Directed evolution: bringing new chemistry to life. Angew Chem Int Ed Eng 57(16):4143-4148. https://doi.org/10. 1002/anie.201708408

Bickerstaff GF (1997) Immobilization of Enzymes and Cells. In: Bickerstaff GF (ed) Immobilization of Enzymes and Cells. Humana Press, Totowa, pp 1-11

Bornscheuer UT, Huisman GW, Kazlauskas RJ, Lutz S, Moore JC, Robins K (2012) Engineering the third wave of biocatalysis. Nature 485(7397):185-194. https://doi.org/10.1038/nature11117

Cendrin F, Chroboczek J, Zaccai G, Eisenberg H, Mevarech M (1993) Cloning, sequencing, and expression in Escherichia coli of the gene coding for malate dehydrogenase of the extremely halophilic archaebacterium Haloarcula marismortui. Biochemistry 32(16):4308 4313

Chibata I (1979) Immobilized microbial cells with polyacrylamide gel and carrageenan and their industrial applications immobilized microbial cells. In ACS Symposium Series, vol 106. Am Chem Soc: 187-202

Connaris H, Chaudhuri JB, Danson MJ, Hough DW (1999) Expression, reactivation, and purification of enzymes from Haloferax volcanii in Escherichia coli. Biotechnol Bioeng 64(1):38-45

Danson MJ, Hough DW (1997) The structural basis of protein halophilicity. Comp Biochem Physiol A Physiol 117(3):307-312. https://doi.org/10.1016/S0300-9629(96)00268-X

de Carvalho CC (2017) Whole cell biocatalysts: essential workers from nature to the industry. Microb Biotechnol 10(2):250-263. https:// doi.org/10.1111/1751-7915.12363

Demirjian DC, Morís-Varas F, Cassidy CS (2001) Enzymes from extremophiles. Curr Opin Chem Biol 5(2):144-151. https://doi. org/10.1016/S1367-5931(00)00183-6

Devaux-Basseguy R, Bergel A, Comtat M (1997) Potential applications of NAD(P)-dependent oxidoreductases in synthesis: a survey. Enzym Microb Technol 20(4):248-258. https://doi.org/10.1016/ S0141-0229(96)00120-2

Freeman A, Woodley JM, Lilly MD (1993) In situ product removal as a tool for bioprocessing. Biotechnology (N Y) 11(9):1007-1012

Gombotz WR, Wee S (1998) Protein release from alginate matrices. Adv Drug Deliv Rev 31(3):267-285. https://doi.org/10.1016/S0169409X(97)00124-5

Gotovtsev PM, Yuzbasheva EY, Gorin KV, Butylin VV, Badranova GU, Perkovskaya NI, Mostova EB, Namsaraev ZB, Rudneva NI, Komova AV, Vasilov RG, Sineokii SP (2015) Immobilization of microbial cells for biotechnological production: modern solutions and promising technologies. Appl Biochem Microbiol 51(8):792803. https://doi.org/10.1134/S0003683815080025

Gungormusler-Yilmaz M, Cicek N, Levin DB, Azbar N (2016) Cell immobilization for microbial production of 1,3-propanediol. Crit Rev Biotechnol 36(3):482-494. https://doi.org/10.3109/07388551. 2014.992386

Hasegawa Y, Adachi S, Matsuno R (1998) Asymmetric reduction of acetophenone by immobilized Hansenula capsulata cells. J Ferment Bioeng 85(3):322-327. https://doi.org/10.1016/S0922338X(97) $85683-8$

Haug A, Larsen B (1966) A study on the constitution of alginic acid by partial acid hydrolysis. In: Young EG, McLachlan JL (eds) Proc Int
Seaweed Sym, Halifax, August 25-28, 1965, Pergamon, pp 271277

Homola P, Kurák T, Illeová V, Polakovič M (2015) Kinetics of acetophenone reduction to (R)-1-phenylethanol by a whole-cell Pichia capsulata biocatalyst. Biocatal Biotransformation 33(5-6): 323-332. https://doi.org/10.3109/10242422.2016.1151007

Hummel W, Gröger H (2014) Strategies for regeneration of nicotinamide coenzymes emphasizing self-sufficient closed-loop recycling systems. J Biotechnol 191:22-31. https://doi.org/10.1016/j.jbiotec. 2014.07.449

Illeová V, Ačai P, Féher J, Polakovič M (2015) Biotransformation of acetophenone to R-1-phenylethanol with immobilized Pichia capsulata in batch reactor. Acta Chim Slov 8(2):107-114. https:// doi.org/10.1515/acs-2015-0019

Ishige T, Honda K, Shimizu S (2005) Whole organism biocatalysis. Curr Opin Chem Biol 9(2):174-180. https://doi.org/10.1016/j.cbpa.2005. 02.001

Janeczko T, Bąkowski W, Walczak E, Robak M, Dmochowska-Gładysz J, Kostrzewa-Susłow E (2015) Biotransformation of acetophenone and its halogen derivatives by Yarrowia lipolytica strains. Ann Microbiol 65(2):1097-1107. https://doi.org/10.1007/s13213-0140955-3

Kometani T, Morita Y, Furui H, Yoshii H, Matsuno R (1994) NAD(P)H regeneration using ethanol as an energy source in baker's yeastmediated bioreduction. J Ferment Bioeng 77(1):13-16. https://doi. org/10.1016/0922-338X(94)90200-3

Kometani T, Morita Y, Kiyama Y, Yoshii H, Matsuno R (1995) Relationship between ethanol consumption rate and prochiral ketone reduction rate in bakers' yeast. J Ferment Bioeng 80(2):208210. https://doi.org/10.1016/0922-338X(95)93222-6

Kurbanoglu EB, Zilbeyaz K, Kurbanoglu NI, Kilic H (2007) Enantioselective reduction of substituted acetophenones by Aspergillus niger. Tetrahedron Asymmetry 18(10):1159-1162. https://doi.org/10.1016/j.tetasy.2007.05.017

Kurbanoglu EB, Zilbeyaz K, Ozdal M, Taskin M, Kurbanoglu NI (2010) Asymmetric reduction of substituted acetophenones using once immobilized Rhodotorula glutinis cells. Bioresour Technol 101(11):3825-3829. https://doi.org/10.1016/j.biortech.2010.01.016

Large A, Stamme C, Lange C, Duan Z, Allers T, Soppa J, Lund PA (2007) Characterization of a tightly controlled promoter of the halophilic archaeon Haloferax volcanii and its use in the analysis of the essential cct1 gene. Mol Microbiol 66(5):1092-1106. https://doi.org/10. $1111 / j .1365-2958.2007 .05980 . x$

Lee KY, Mooney DJ (2012) Alginate: properties and biomedical applications. Prog Polym Sci 37(1):106-126. https://doi.org/10.1016/j. progpolymsci.2011.06.003

Lin B, Tao Y (2017) Whole-cell biocatalysts by design. Microb Cell Factories 16(1):106. https://doi.org/10.1186/s12934-017-0724-7

Martinsen A, Skjåk-Bræk G, Smidsrød O (1989) Alginate as immobilization material: I. correlation between chemical and physical properties of alginate gel beads. Biotechnol Bioeng 33(1):79-89. https:// doi.org/10.1002/bit.260330111

Melvik JE, Dornish M (2004) Alginate as a carrier for cell immobilisation. In: Nedović V, Willaert R (eds) Fundamentals of Cell Immobilisation Biotechnology. Springer Netherlands, Dordrecht, pp 33-51

Mevarech M, Frolow F, Gloss LM (2000) Halophilic enzymes: proteins with a grain of salt. Biophys Chem 86(2):155-164. https://doi.org/ 10.1016/S0301-4622(00)00126-5

Morch YA, Donati I, Strand BL, Skjak-Braek G (2006) Effect of $\mathrm{Ca}^{2+}$, $\mathrm{Ba}^{2+}$, and $\mathrm{Sr}^{2+}$ on alginate microbeads. Biomacromolecules 7(5): 1471-1480. https://doi.org/10.1021/bm060010d

Mørch YA, Qi M, Gundersen POM, Formo K, Lacik I, Skjåk-Braek G, Oberholzer J, Strand BL (2012) Binding and leakage of barium in alginate microbeads. J Biomed Mater Res A 100(11):2939-2947. https://doi.org/10.1002/jbm.a.34237 
Mullakhanbhai MF, Larsen H (1975) Halobacterium volcanii spec. nov., a Dead Sea halobacterium with a moderate salt requirement. Arch Microbiol 104(3):207-214

Oren A (2010) Industrial and environmental applications of halophilic microorganisms. Environ Technol 31(8-9):825-834. https://doi. org/10.1080/095933330903370026

Porta R, Benaglia M, Puglisi A (2016) Flow chemistry: recent developments in the synthesis of pharmaceutical products. Org Process Res Dev 20(1):2-25. https://doi.org/10.1021/acs.oprd.5b00325

Schmid A, Dordick JS, Hauer B, Kiener A, Wubbolts M, Witholt B (2001) Industrial biocatalysis today and tomorrow. Nature 409(6817):258-268. https://doi.org/10.1038/35051736

Schoemaker HE, Mink D, Wubbolts MG (2003) Dispelling the mythsbiocatalysis in industrial synthesis. Science 299(5613):1694-1697. https://doi.org/10.1126/science.1079237

Sheldon RA, Woodley JM (2018) Role of biocatalysis in sustainable chemistry. Chem Rev 118(2):801-838. https://doi.org/10.1021/acs. chemrev.7b00203

Smidsrød O (1974) Molecular basis for some physical properties of alginates in the gel state. Faraday Discuss 57(0):263-274. https://doi. org/10.1039/DC9745700263

Smidsrod O, Skjak-Braek G (1990) Alginate as immobilization matrix for cells. Trends Biotechnol 8(3):71-78

Strand BL, Skjåk-Bræk G, Gåserød O (2004) Microcapsule formulation and formation. In: Nedović V, Willaert R (eds) Fundamentals of Cell Immobilisation Biotechnology. Springer Netherlands, Dordrecht, pp $165-183$

Strillinger E, Grotzinger SW, Allers T, Eppinger J, Weuster-Botz D (2016) Production of halophilic proteins using Haloferax volcanii H1895 in a stirred-tank bioreactor. Appl Microbiol Biotechnol 100(3):1183-1195. https://doi.org/10.1007/s00253-015-7007-1

Tamborini L, Romano D, Pinto A, Contente M, Iannuzzi MC, Conti P, Molinari F (2013) Biotransformation with whole microbial systems in a continuous flow reactor: resolution of (RS)-flurbiprofen using Aspergillus oryzae by direct esterification with ethanol in organic solvent. Tetrahedron Lett 54(45):6090-6093. https://doi.org/10. 1016/j.tetlet.2013.08.119

Tamborini L, Fernandes P, Paradisi F, Molinari F (2018) Flow bioreactors as complementary tools for biocatalytic process intensification. Trends Biotechnol 36(1):73-88. https://doi.org/10.1016/j.tibtech. 2017.09.005

Timpson LM, Alsafadi D, Mac Donnchadha C, Liddell S, Sharkey MA, Paradisi F (2012) Characterization of alcohol dehydrogenase (ADH12) from Haloarcula marismortui, an extreme halophile from the Dead Sea. Extremophiles 16(1):57-66. https://doi.org/10.1007/ s00792-011-0405-0
Timpson LM, Liliensiek AK, Alsafadi D, Cassidy J, Sharkey MA, Liddell S, Allers T, Paradisi F (2013) A comparison of two novel alcohol dehydrogenase enzymes (ADH1 and ADH2) from the extreme halophile Haloferax volcanii. Appl Microbiol Biotechnol 97(1):195-203. https://doi.org/10.1007/ s00253-012-4074-4

Topuz F, Henke A, Richtering W, Groll J (2012) Magnesium ions and alginate do form hydrogels: a rheological study. Soft Matter 8(18): 4877-4881. https://doi.org/10.1039/C2SM07465F

Tufvesson P, Lima-Ramos J, Nordblad M, Woodley JM (2011) Guidelines and cost analysis for catalyst production in biocatalytic processes. Org Process Res Dev 15(1):266-274. https://doi.org/10. 1021/op1002165

Valadez-Blanco R, Livingston AG (2009) Enantioselective whole-cell biotransformation of acetophenone to S-phenylethanol by Rhodotorula glutinis. Part II. Aqueous-organic systems: emulsion and membrane bioreactors. Biochem Eng J 46(1):54-60. https://doi. org/10.1016/j.bej.2009.05.010

Vicini S, Mauri M, Wichert J, Castellano M (2017) Alginate gelling process: use of bivalent ions rich microspheres. Polym Eng Sci 57(6):531-536. https://doi.org/10.1002/pen.24552

Wachtmeister J, Rother D (2016) Recent advances in whole cell biocatalysis techniques bridging from investigative to industrial scale. Curr Opin Biotechnol 42:169-177. https://doi.org/10.1016/j. copbio.2016.05.005

Wideroe H, Danielsen S (2001) Evaluation of the use of $\mathrm{Sr}^{2+}$ in alginate immobilization of cells. Naturwissenschaften 88(5):224-228

Yadav VG, De Mey M, Giaw Lim C, Kumaran Ajikumar P, Stephanopoulos G (2012) The future of metabolic engineering and synthetic biology: towards a systematic practice. Metab Eng 14(3):233-241. https://doi.org/10.1016/j.ymben. 2012.02.001

Zhao W, Huang J, Peng C, Hu S, Ke P, Mei L, Yao S (2014) Permeabilizing Escherichia coli for whole cell biocatalyst with enhanced biotransformation ability from l-glutamate to GABA. J Mol Catal B Enzym 107:39-46

Zhu Y (2007) Chapter 14 - Immobilized cell fermentation for production of chemicals and fuels. In: Yang S-T (ed) Bioprocessing for ValueAdded Products from Renewable Resources. Elsevier, Amsterdam, pp 373-396

Publisher's note Springer Nature remains neutral with regard to jurisdictional claims in published maps and institutional affiliations. 